\title{
Effects of Walking on Coronary Heart Disease in Elderly Men with Diabetes
}

\author{
Chieko Kimata ${ }^{1, *}$, Bradley Willcox ${ }^{2}$ and Beatriz L. Rodriguez ${ }^{2,3}$ \\ 1 Patient Safety \& Quality Services, Hawai'i Pacific Health, Honolulu, HI 96813, USA \\ 2 Department of Geriatric Medicine, John A. Burns School of Medicine, University of Hawai'i at Mānoa, \\ Honolulu, HI 96817, USA; willcox@hawaii.edu (B.W.); brodrigu@hawaii.edu (B.R.) \\ 3 Escuela de Medicina, Tecnologico de Monterrey, Monterrey, NL 64710, Mexico \\ * Correspondence: chieko.kimata@hawaiipacifichealth.org; Tel.: +1-808-429-1082
}

Received: 13 March 2018; Accepted: 15 April 2018; Published: 19 April 2018

check for updates

\begin{abstract}
Previous studies have shown that walking is associated with increased longevity and a reduced risk of cardiovascular and age-related diseases. Whether walking benefits individuals with diabetes who are at high risk of coronary heart disease (CHD) remains to be determined. The objective of this study is to examine the association between walking and risk of CHD among elderly men with and without diabetes. Walking data was assessed in 2732 men aged 71 to 93 years participating in the Honolulu Heart Program from 1991-1993. Study participants were initially without disabilities and free of prevalent CHD. Men were then followed for incident CHD for up to 7 years. For men with diabetes who walked $<0.25$ miles/day, the age-adjusted incidence of CHD was significantly higher than in men without diabetes (27.1 vs. $12.7 / 1000$ person years, $p=0.026)$. In contrast when distance walked was $>1.5$ miles / day, incidence of CHD was similar in men with and without diabetes (12.2 vs. 9.1/1000 person-years, $p=0.46$ ). While risk of CHD declined significantly with increasing walking distance in men with diabetes after age and risk factor adjustment $(p=0.043, p=0.025)$, associations in those without diabetes were weaker $(p=0.070, p=0.10)$. These findings suggest that among elderly men with diabetes who are capable of physical activity, walking reduces CHD risk to levels similar to when diabetes is absent. Walking is an easy, safe and accessible form of physical activity that may have marked health benefits for elderly men with diabetes.
\end{abstract}

Keywords: coronary heart disease; diabetes; walking; Honolulu Heart Program; elderly men

\section{Introduction}

Evidence suggests that walking is associated with increased longevity and a reduced risk of cardiovascular and age-related diseases [1-4]. Other benefits of walking include lowered blood pressure, reduced body weight and improved glucose and lipid metabolism [5]. Some research also shows exercise brings health benefits to people with diabetes [6-8]. Diabetes greatly increases the risk of future cardiovascular morbidity and mortality [9-12]. Whether walking provides benefits for elderly diabetic individuals who may possess a high risk of coronary heart disease (CHD) remains to be determined. The purpose of this research is to examine the association between walking and CHD incidence in elderly men with diabetes. Findings are based on longitudinal follow-up of a population-based sample of Japanese-American men aged 71 to 93 years who were enrolled in the Honolulu Heart Program without prevalent CHD. 


\section{Materials and Methods}

\subsection{Study Population}

The Honolulu Heart Program, established in 1965, is a prospective study of cardiovascular disease and stroke [13-16]. The target population was comprised of 8006 Japanese-American men aged 45-68 at baseline examination and living on the island of Oahu, Hawai'i. This analysis included survivors of the original cohort who participated in the 1991-1993 examination, when men were 71-93 years old. They were followed until 1998 for the development of incident CHD. Only men who were capable of physical activity were considered for this study. Men were considered to be capable of physical activity if they participated in a baseline clinical examination at the Kuakini Medical Center and reported they could undertake more than $1 \mathrm{~h}$ of slight, moderate or heavy activity in a typical 24-h period [4]. The sample size was 2637 after excluding those who were not eligible and those who did not have information on walking distance or diabetes status.

\subsection{Measures}

The average walking distance per day was asked of the participants at baseline examination [16]. Walking distance was treated as both a continuous variable and as a categorical variable. Categorically, variables were divided into three groups: less than 0.25 miles/day, between 0.25 and 1.5 miles/day and over 1.5 miles/day [4].

CHD events were acquired by a comprehensive surveillance of hospital discharge registers, health certificates, autopsy records and by repeating examinations during follow-ups. CHD was defined as unequivocal findings through hospital surveillance of nonfatal myocardial infarction with ECG or cardiac enzyme evidence, coronary death and sudden death within an hour that could not be attributed to another cause [4]. Medical history or a fasting glucose greater than $125 \mathrm{mg} / \mathrm{dL}$ was used to determine diabetes at the 1991-1993 examination [11]. Additional data on cardiovascular disease (CVD) risk factors in this cohort have been previously published [4,11-16].

\subsection{Statistical Analysis}

An age-adjusted incidence rate per 1000 (person-years) was calculated for CHD outcome by direct method of standardization using the Honolulu Heart Program population in the 1991-1993 examination. To describe the difference in incidence rates between men with diabetes and without diabetes, the cox model was used. To identify possible confounding variables between diabetic status and walking distance categories, the age-adjusted mean level of individual factors was calculated across the ranges of walking distances with the ANCOVA method using linear and logistic regression models [17]. To examine the independent effects of walking distance, possible confounding variables were adjusted in separate models. These confounders included age, body mass index (BMI), systolic blood pressure (SBP), fasting glucose, total and high-density lipoprotein (HDL) cholesterol, alcohol consumption and smoking [12,18].

Proportional hazard regression models were used to estimate the Relative Risk (RR) for the higher two levels of walking distance using the lowest level ( $<0.25$ miles / day) as a reference group for men with and without diabetes separately. A test for trend was done using walking distance as a continuous variable to examine a dose-response relationship between walking and CHD risk. The statistical analysis was performed using the SAS statistical software version 9.3 (SAS Institute, Cary, NC, USA). A $p$-value of $<0.05$ was considered statistically significant.

\section{Results}

Among the 2637 men capable of physical activity and free of CHD, 538 (20\%) had diabetes and $2109(80 \%)$ did not have diabetes. The study average walking distance was $1.2 \pm 1.4$ miles. Among men with diabetes, 30\% walked $<0.25$ miles/day, $41 \%$ walked 0.25 to 1.5 miles/day and $29 \%$ walked $>1.5$ miles / day, while $30 \%, 39 \%$ and $31 \%$ of men without diabetes walked these amounts, respectively. 
The number of men with diabetes and without diabetes who developed new CHD events was 61 (20.1 per 1000 person-years) and 149 (12.0 per 1000 person-years), respectively (Table 1).

Table 1. Age-Adjusted Incidence rate, 1000 person-years of Coronary Heart Disease (CHD) Based on 5 to 7 years of Follow-Up According to Walking Distance in Elderly Men Aged 71 to 93 years among men with diabetes and without diabetes.

\begin{tabular}{ccccccc}
\hline \multirow{2}{*}{$\begin{array}{c}\text { Walking } \\
\text { Distance, } \\
\text { miles/day }\end{array}$} & \multicolumn{2}{c}{ Number of Subjects (\%) } & \multicolumn{2}{c}{ Number of Events (\%) } & \multicolumn{2}{c}{$\begin{array}{c}\text { Age-Adjusted Incidence Rate, } \\
\text { per 1000 Person-Years (95\% CI) }\end{array}$} \\
\cline { 2 - 7 } & $\begin{array}{c}\text { With } \\
\text { Diabetes }\end{array}$ & $\begin{array}{c}\text { Without } \\
\text { Diabetes }\end{array}$ & $\begin{array}{c}\text { With } \\
\text { Diabetes }\end{array}$ & $\begin{array}{c}\text { Without } \\
\text { Diabetes }\end{array}$ & With Diabetes & $\begin{array}{c}\text { Without } \\
\text { Diabetes }\end{array}$ \\
\hline$<0.25$ & $161(30)$ & $633(30)$ & $23(38)$ & $44(30)$ & $27.1(24.6-29.6)^{*}$ & $12.7(11.6-13.9)^{*}$ \\
0.25 to 1.5 & $220(41)$ & $831(39)$ & $27(44)$ & $69(46)$ & $23.2(21.2-25.1)^{*}$ & $13.9(12.3-15.0)^{*}$ \\
$>1.5$ & $157(29)$ & $645(31)$ & $11(18)$ & $36(24)$ & $12.2(4.7-19.6)$ & $9.1(6.0-12.0)$ \\
\hline
\end{tabular}

* Significant difference between men with diabetes and without diabetes.

The age-adjusted CHD incidence rate per 1000 person-years was higher for men with diabetes than men without diabetes in all groups of walking distances, with significant differences noted in subjects who walked $<0.25$ miles/day $(p=0.026)$ and those who walked from 0.25 to 1.5 miles/day $(p=0.044)$. Conversely, the age-adjusted CHD incidence rate was similar among men with diabetes and without diabetes for those who reported walking $>1.5$ miles per day (Table 1 and Figure 1).

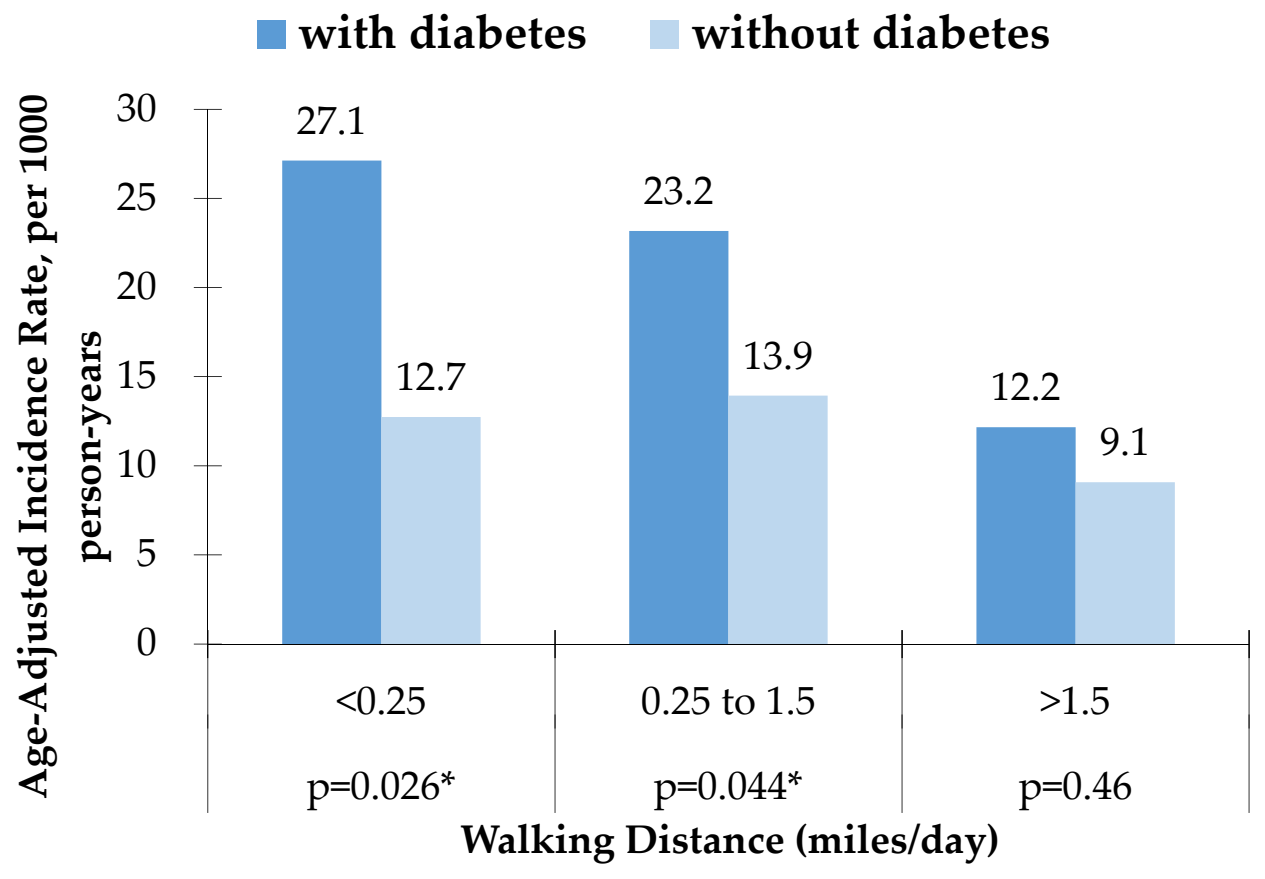

Figure 1. Age-Adjusted Incidence rate, per 1000 person-years of CHD among men with diabetes and without diabetes. * Significant difference between men with diabetes and without diabetes.

Table 2 shows other risk factors associated with walking distance at baseline examination. Younger men were more likely to walk longer distances in both diabetic and non-diabetic categories. Among men without diabetes, those who walked $<0.25$ miles/day had significantly lower SBP than those who walked $>1.5$ miles/day. Men who walked $<0.25$ miles/day were more likely to be smokers than those who walked $>1.5$ miles/day $(p<0.05)$. There were no associations observed between walking distance and body mass index, fasting glucose, total and HDL cholesterol, or alcohol intake. 
Table 2. Age-Adjusted Mean Levels (SD) and percent of Selected Risk Factors for CHD at Time of Baseline Examination (1991-1993) According to Walking Distance per Day among men with diabetes and without diabetes.

\begin{tabular}{|c|c|c|c|c|c|c|}
\hline \multirow{3}{*}{ Baseline (1991-1993) Risk Factor } & \multicolumn{6}{|c|}{ Walking Distance, miles/day } \\
\hline & \multicolumn{2}{|c|}{$<0.25$ miles/day } & \multicolumn{2}{|c|}{0.25 to $1.5 \mathrm{miles} / \mathrm{day}$} & \multicolumn{2}{|c|}{$>1.5$ miles/day } \\
\hline & $\begin{array}{c}\text { With } \\
\text { Diabetes }\end{array}$ & $\begin{array}{l}\text { Without } \\
\text { Diabetes }\end{array}$ & $\begin{array}{c}\text { With } \\
\text { Diabetes }\end{array}$ & $\begin{array}{l}\text { Without } \\
\text { Diabetes }\end{array}$ & $\begin{array}{c}\text { With } \\
\text { Diabetes }\end{array}$ & $\begin{array}{l}\text { Without } \\
\text { Diabetes }\end{array}$ \\
\hline Age & $77.4(4.6)$ & $77.60(4.3) \ddagger$ & $77.2(3.9)^{+}$ & $77.6(4.3) \S$ & $76.2(3.5)$ & $76.6(3.9)$ \\
\hline BMI & $24.0(3.4)$ & $23.2(3.3)$ & $23.8(3.3)$ & $23.3(3.0)$ & $24.1(2.8)$ & $23.5(2.9)$ \\
\hline Fasting glucose, mg/dL & $144.9(42.1)$ & $103.0(9.1)$ & $145.5(45.2)$ & $102.7(8.4)$ & $146.9(45.4)$ & $103.5(8.6)$ \\
\hline Total cholesterol, mg/dL & 190.4 (190.4) & $191.5(34.2)$ & $190.6(34.9)$ & $190.4(31.8)$ & $193.5(32.4)$ & $194.8(31.4)$ \\
\hline HDL cholesterol, mg/dL & $48.3(11.0)$ & $53.3(13.8)$ & $49.2(14.9)$ & $52.1(13.6)$ & $48.6(12.4)$ & $52.6(12.8)$ \\
\hline SBP, $\mathrm{mmHg}$ & $153.0(24.5)$ & $148.9(23.2)^{+}$ & $151.3(22.7)$ & $149.4(22.0)$ & $154.6(23.7)$ & $150.9(22.4)$ \\
\hline Current smoker, \% & $7.8^{\dagger}$ & $11.3 \ddagger$ & 5.90 & 7.30 & 2.50 & 5.40 \\
\hline Alcohol intake, oz/month & $21.4(45.2)$ & $20.3(40.1)$ & $25.1(57.6)$ & $20.3(41.6)$ & $13.7(26.0)$ & $17.1(33.7)$ \\
\hline
\end{tabular}

After adjustments for age, BMI, SBP, fasting glucose, total and HDL cholesterol, alcohol consumption and smoking, the RR of CHD among men with diabetes was 0.45 (95\% CI: 0.22-0.93) for those who walked $>1.5$ miles / day compared to men who walked $<0.25$ miles/day and 0.81 ( $95 \%$ CI: $0.47-1.41$ ) in men who walked 0.25 to 1.5 miles/day compared to men who walked $<0.25$ miles/day. Among men without diabetes, the RR of CHD was 0.74 (95\% CI: 0.47-1.17) in men who walked $>1.5$ miles/day compared to men who walked $<0.25$ miles/day and 1.16 (95\% CI: 0.78-1.72) in men who walked 0.25 to 1.5 miles/day compared to men who walked $<0.25$ miles/day. There was no statistically significant interaction of diabetes with walking distance. Among men with diabetes, there was an inverse trend of walking distance and $\operatorname{CHD}(p=0.043$ with age-adjustment, $p=0.025$ with risk factor-adjustment). This trend missed the significance level among those without diabetes ( $p=0.070$ with age-adjustment and $p=0.10$ with risk factor-adjustment). In this analysis, walking distance was used as a continuous variable (Table 3 ).

Table 3. Estimated Age-Adjusted and Risk Factor-Adjusted Relative Risks of CHD Comparing Ranges of Walking Distance per Day among men with diabetes and without diabetes.

\begin{tabular}{ccccc}
\hline \multirow{2}{*}{$\begin{array}{c}\text { Walking Distance, } \\
\text { miles/day }\end{array}$} & \multicolumn{2}{c}{ Age-Adjusted Relative Risk (95\% CI) } & \multicolumn{2}{c}{ Risk Factor-Adjusted Relative Risk $\mathbf{( 9 5 \% ~ C l ) ~ * ~}$} \\
\cline { 2 - 5 } & With Diabetes & Without Diabetes & With Diabetes & Without Diabetes \\
\hline$<0.25^{\dagger}$ & 1 & 1 & 1 & 1 \\
0.25 to 1.5 & $0.77(0.45-1.32)$ & $1.07(0.75-1.54)$ & $0.81(0.47-1.41)$ & $1.16(0.78-1.72)$ \\
$>1.5$ & $0.48(0.24-0.98)^{\ddagger}$ & $0.70(0.46-1.07)$ & $0.45(0.22-0.93) \ddagger$ & $0.74(0.47-1.17)$ \\
test for trend $\AA$ & $p=0.043$ & $p=0.070$ & $p=0.025$ & $p=0.10$ \\
\hline
\end{tabular}

* RRs are adjusted for age, BMI, SBP, fasting glucose, total and HDL cholesterol, alcohol consumption, and smoking; ${ }^{\dagger}$ Used the lowest level of walking $(<0.25)$ as a reference group against higher levels of walking; ${ }^{\ddagger}$ Significant excess of CHD $(p<0.05) ; \S$ Walking distance was treated as a continuous variable in test for trend.

\section{Discussion}

According to a former study by the Honolulu Heart Program, walking was associated with a reduced risk of CHD in elderly men [4]. However, the effect of walking among men with diabetes and without diabetes was not examined in the previous investigation. This study considered CHD incidence among men with diabetes and without diabetes separately and the follow-up period was longer than the former study ( 1 to 3 years versus 5 to 7 years). Additionally, only men who were capable of physical activity were considered.

Having diabetes is known to increase the risk of CHD. This research suggests there is a protective effect of walking distance on CHD. This effect is stronger among men with diabetes than men without diabetes the longer the daily average walking distance. Men with diabetes who walked $>1.5$ miles/day had reduced levels of risk, similar to men without diabetes. Although in need of confirmation, this 
study suggests regularly walking 1.5 miles per day or more could be an effective way of reducing the risk of CHD in elderly men with diabetes.

One of the strengths of this paper is the quality of the data. The Honolulu Heart Program is one of the largest studies of CVD in a minority population in the United States. Comprehensive examinations were conducted with quality control and standardized procedures [19]. The Honolulu Heart Program also provides high quality longitudinal data that enables researchers to obtain prospective CHD outcomes from a comprehensive surveillance system. This includes review of examination results, all hospital discharge summaries, autopsy reports and death certificates [20]. Furthermore, approximately $80 \%$ of cohort survivors participated in the 1991-1993 examination. The study was also conducted on the island of Oahu and because of its' isolation, the migration rate was very low. Only 5 participants were lost to follow-up of the original 8006 subjects between 1965 and 1993. Few patients left Oahu to receive medical care.

A limitation this study did not consider is the intensity and duration of walking. However, another Honolulu Heart Program study analyzed the time to walk 10 feet (intensity) and time spent in slight activities (duration in activities similar to casual walking) [16]. Another study also commented that there was a relationship between strength and power to walking behaviors in older adults [21]. Strength and duration of walking may be related to the amount of benefits from walking. This study also did not consider different forms of physical activities such as running, biking, swimming and so forth, as the participants were 71 to 93 years old and only a small percentage of men were engaged in heavy activities. However, many studies in younger populations showed a reduction in cardiovascular risks with these type of physical activities [22-25]. This investigation only included Japanese-American males. It is unclear if the findings of a sample of Japanese-American men apply to other population segments. In general however, risk factor associations with several disease endpoints in the sample from Hawai'i closely agree with findings reported elsewhere, including relationships with CHD, dementia and Parkinson's disease [16,26-30]. In direct comparison with the Framingham Study, similar risk factor effects on the incidence of stroke were observed [26]. Additional research among elderly women would lend support to our analysis, although findings are likely to be similar to those reported here [31,32]. In this analysis, only baseline data of walking distance and biological characteristics were considered, therefore, beneficial effects on biological mechanisms from walking distance were not examined in this project. However, several studies have found that low-intensity exercise such as walking is strongly associated with lower blood pressure, lower insulin resistance, increased levels of HDL cholesterol, more efficient glucose metabolism and reduced levels of body fat $[4,5]$. These beneficial effects on biological mechanisms may consequently prevent the metabolic syndrome [33] and decrease developing CVD [34,35]. Physical activity may also bring high quality of life and well-being for elderly people [36].

In this study population, $17 \%$ had a history of diabetes. Most of them were taking oral hypoglycemic agents and only a small percentage of participants were taking insulin (2.5\%) [12]. Therefore, we did not consider the functional role of insulin therapy in the outcome, although insulin therapy might reduce the risk of CVD in elderly people [37,38].

The reduction in the risk of CHD among individuals with diabetes is likely due to the beneficial effects of walking on glucose metabolism, including fasting and $2 \mathrm{~h}$ post load glucose levels $[1,11]$. This cohort has shown that both fasting and $2 \mathrm{~h}$ post load glucose levels are independently associated with CVD, after taking other established CVD risk factors into account [11]. Although the exact mechanism by which walking distance leads to a decrease in CHD incidence, independently of the risk factors we adjusted for, is not known, we hypothesize that walking leads to improved insulin sensitivity and better glucose control of both fasting and post load glucose. Furthermore, we estimate this process positively correlates with walking distance.

Given that walking is known to have significant health benefits in persons tolerant of moderate exercise, it is recommended to encourage older individuals with diabetes who are capable of physical activity to engage in walking on a daily basis with the approval of their physicians. The present study 
considered only men who are capable of physical activity. However, diabetes is a major cause of disability in the elderly population. They are also at high risk of CHD in the United States [39-42], therefore further research on the relationship between diabetes and disabilities is recommended. In addition, further data from clinical trials and intervention studies conducted in populations with diabetes would provide evidence to confirm these very encouraging findings for the prevention of CHD in older people with diabetes.

\section{Conclusions}

These findings suggest that among men with diabetes who are capable of physical activity, walking reduces CHD risk to levels similar to those of men without diabetes. Walking is an easy, safe, accessible, feasible and inexpensive form of physical activity for all ages and this investigation indicates it is especially useful among individuals with diabetes.

Acknowledgments: This study was supported by a contract (NO1-HC-05102) from the National Heart, Lung and Blood Institute and by a Clinical Research Education and Career Development (CRECD) in Minority Institutions (R25 RR01931) from the National Institutes of Health, Bethesda, MD. We thank PhD in Biomedical Science Program in Clinical Research (K07 GM072884, Curriculum Development Award in Interdisciplinary Research), University of Hawai'i, John A. Burns School of Medicine for providing us the necessary research work. We also thank J. David Curb, Katsuhiko Yano, Kuakini Medical Center, Honolulu Hawai'i, Robert Abbott, Shiga University of Medical Science, Shiga, Japan, Rosanne Harrigan, John S. Grove, David Easa, Jim Davis and Zoë Hammatt, University of Hawai'i at Manoa, Honolulu, Hawai'i, for their helpful research assistance. We would like to thank Kyle Okumura for manuscript editing and proofreading.

Author Contributions: B.R. and C.K. conceived the presented idea. B.R. and B.W. supervised the findings of this work. C.K. analyzed the data and wrote the paper. Authorship must be limited to those who have contributed substantially to the work reported.

Conflicts of Interest: The authors declare no conflicts of interest.

\section{References}

1. Thompson, P.D.; Buchner, D.; Pina, I.L.; Balady, G.J.; Williams, M.A.; Marcus, B.H.; Berra, K.; Blair, S.N.; Costa, F.; Franklin, B.; et al. American Heart Association Council on Clinical Cardiology Subcommittee on Exercise, Rehabilitation and Prevention; American Heart Association Council on Nutrition, Physical Activity and Metabolism Subcommittee on Physical Activity. Circulation 2003, 107, e9053-e9054. [CrossRef] [PubMed]

2. Press, V.; Freestone, I.; George, C.F. Physical activity: The evidence of benefit in the prevention of coronary heart disease. QJM 2003, 96, 245-251. [CrossRef] [PubMed]

3. Kannel, W.B.; Sorlie, P. Some health benefits of physical activity. Arch. Intern. Med. 1979, 139, 857-861. [CrossRef] [PubMed]

4. Hakim, A.A.; Curb, J.D.; Petrovitch, H.; Rodriguez, B.L.; Yano, K.; Ross, G.W.; White, L.R.; Abbott, R.D. Effects of walking on Coronary Heart disease in elderly men: The Honolulu Heart Program. Circulation 1999, 100, 9-13. [CrossRef] [PubMed]

5. Ghosh, A. Effects of daily exercise on blood pressure, plasma glucose and obesity measures in 55-64-year-old obese Asia Indian men: The Calcutta longitudinal study. Am. J. Hum. Biol. 2006, 18, 718-721. [CrossRef] [PubMed]

6. Chimen, M.; Kennedy, A.; Nirantharakumar, K.; Pang, T.T.; Andrews, R.; Narendran, P. What are the health benefits of physical activity in type 1 diabetes mellitus? A literature review. Diabetologia 2012, 55, 542-551. [CrossRef] [PubMed]

7. Colberg, S.R.; Sigal, R.J.; Fernhall, B.; Regensteiner, J.G.; Blissmer, B.J.; Rubin, R.R.; Chasan-Taber, L.; Albright, A.L.; Braun, B. Exercise and type 2 diabetes: American college of sports medicine and the American diabetes association: Joint position statement. Med. Sci. Sport Exerc. 2010, 42, 2282-2303.

8. Najafipour, F.; Mobasseri, M.; Yavari, A.; Nadrian, H.; Aliasgarzadeh, A.; Mashinchi Abbasi, N.; Niafar, M.; Houshyar Gharamaleki, J.; Sadra, V. Effect of regular exercise training on changes in HbA1c, BMI and $\mathrm{VO}(2)$ max among patients with type 2 diabetes mellitus: An 8-year trial. BMJ Open Diabetes Res. Care 2017, 5, e000414. [CrossRef] 
9. Paffenbarger, R.S.; Hyde, R.T.; Wing, A.L.; Lee, I.; Jung, D.L.; Kampert, J.B. The association of changes in physical-activity level and other lifestyle characteristics with mortality among men. N. Engl. J. Med. 1993, 328, 538-545. [CrossRef] [PubMed]

10. Gregg, E.W.; Gerzoff, R.B.; Caspersen, C.J.; Williamson, D.F.; Narayan, K.M. Relationship of walking to mortality among US adults with diabetes. Arch. Intern. Med. 2003, 163, 1440-1447. [CrossRef] [PubMed]

11. Rodriguez, B.L.; Abbott, R.D.; Fujimoto, W.; Waitzfelder, B.; Chen, R.; Masaki, K.; Schatz, I.; Petrovitch, H.; Ross, W.; Yano, K.; et al. The American Diabetes Association and World Health Organization classifications for diabetes: Their impact on diabetes prevalence and total and cardiovascular disease mortality in elderly Japanese-American men. Diabetes Care 2002, 25, 951-955. [CrossRef]

12. Rodriguez, B.L.; Curb, J.D.; Burchfiel, C.M.; Huang, B.; Sharp, D.S.; Lu, G.Y.; Fujimoto, W.; Yano, K. Impaired glucose tolerance, diabetes and cardiovascular disease risk factor profiles in the elderly: The Honolulu Heart Program. Diabetes Care 1996, 19, 587-590. [CrossRef] [PubMed]

13. Yano, K.; Reed, D.M.; McGee, D.L. Ten-year incidence of coronary heart disease in the Honolulu Heart Program: Relationship to biologic and lifestyle characteristics. Am. J. Epidemiol. 1984, 119, 653-666. [CrossRef] [PubMed]

14. Hakim, A.A.; Petrovitch, H.; Burchfiel, C.M.; Ross, G.W.; Rodriguez, B.L.; White, L.R.; Yano, K.; Curb, J.D.; Abbott, R.D. Effects of walking on mortality among nonsmoking retired men. N. Engl. J. Med. 1998, 338, 94-99. [CrossRef] [PubMed]

15. Rodriguez, B.L.; Lau, N.; Burchfiel, C.M.; Abbott, R.D.; Sharp, D.S.; Yano, K.; Curb, J.D. Glucose intolerance and 23-year risk of coronary heart disease and total mortality. Diabetes Care 1999, 22, 1262-1265. [CrossRef] [PubMed]

16. Abbott, R.D.; White, L.R.; Ross, G.W.; Masaki, K.H.; Curb, J.D.; Petrovitch, H. Walking and dementia in physically capable elderly men. JAMA 2004, 292, 1447-1453. [CrossRef]

17. Lane, P.W.; Nelder, J.A. Analysis of covariance and standardization as instances of prediction. Biometrics 1982, 38, 613-621. [CrossRef]

18. Burchfiel, C.M.; Abbott, R.D.; Sharp, D.S.; Curb, J.D.; Rodriguez, B.L.; Yano, K. Distribution and correlates of lipids and lipoproteins in elderly Japanese-American men: The Honolulu Heart Program. Arterioscler. Thromb. Vasc. Biol. 1996, 16, 1356-1364. [CrossRef] [PubMed]

19. Burchfiel, C.M.; Curb, J.D.; Sharp, D.S.; Rodriguez, B.L.; Arakaki, R.; Chyou, P.H.; Yano, K. Distribution and correlates of insulin in elderly men. The Honolulu Heart Program. Arterioscler. Thromb. Vasc. Biol. 1995, 15, 2213-2221. [CrossRef]

20. Rhoads, G.G.; Kagan, A.; Yano, K. Usefulness of community surveillance for the ascertainment of coronary heart disease and stroke. Int. J. Epidemiol. 1975, 4, 265-270. [CrossRef] [PubMed]

21. Puthoff, M.L.; Janz, K.F.; Nielson, D. The relationship between lower extremity strength and power to everyday walking behaviors in older adults with functional limitations. J. Geriatr. Phys. Ther. 2008, 31, $24-31$. [CrossRef] [PubMed]

22. Lee, D.C.; Pate, R.R.; Lavie, C.J.; Sui, X.; Church, T.S.; Blair, S.N. Leisure-time running reduces all-cause and cardiovascular mortality risk. J. Am. Coll. Cardiol. 2014, 64, 472-481. [CrossRef] [PubMed]

23. Grøntved, A.; Koivula, R.W.; Johansson, I.; Wennberg, P.; Østergaard, L.; Hallmans, G.; Renström, F.; Franks, P.W. Bicycling to Work and Primordial Prevention of Cardiovascular Risk: A Cohort Study Among Swedish Men and Women. J. Am. Heart Assoc. 2016, 5, e004413. [CrossRef] [PubMed]

24. Nualnim, N.; Parkhurst, K.; Dhindsa, M.; Tarumi, T.; Vavrek, J.; Tanaka, H. Effects of swimming training on blood pressure and vascular function in adults $>50$ years of age. Am. J. Cardiol. 2012, 109, 1005-1010. [CrossRef] [PubMed]

25. Nualnim, N.; Barnes, J.N.; Tarumi, T.; Renzi, C.P.; Tanaka, H. Comparison of central artery elasticity in swimmers, runners and the sedentary. Am. J. Cardiol. 2011, 107, 783-787. [CrossRef]

26. Rodriguez, B.L.; D’Agostino, R.; Abbott, R.D.; Kagan, A.; Burchfiel, C.M.; Yano, K.; Ross, G.W.; Silbershatz, H.; Higgins, M.W.; Popper, J.; et al. Risk of hospitalized stroke in men enrolled in the Honolulu Heart Program and the Framingham Study: A comparison of incidence and risk factor effects. Stroke 2002, 33, 230-237. [CrossRef]

27. Yano, K.; Reed, D.; Kagan, A. Coronary heart disease and stroke among Japanese-American men in Hawaii: The Honolulu Heart Program. Hawaii Med. J. 1985, 44, 297-300. [PubMed] 
28. Weuve, J.; Kang, J.H.; Manson, J.E.; Breteler, M.M.B.; Ware, J.H.; Grodstein, F. Physical activity, including walking and cognitive function in older women. JAMA 2004, 292, 1454-1461. [CrossRef] [PubMed]

29. Petrovitch, H.; Ross, G.W.; Abbott, R.D.; Sanderson, W.T.; Sharp, D.S.; Tanner, C.M.; Masaki, K.H.; Blanchette, P.L.; Popper, J.S.; Foley, D.; et al. Plantation work and risk of Parkinson disease in a population-based longitudinal study. Arch. Neurol. 2002, 59, 1787-1792. [CrossRef] [PubMed]

30. Ascherio, A.; Chen, H.; Weisskopf, M.G.; O’Reilly, E.; McCullough, M.L.; Calle, E.E.; Schwarzschild, M.A.; Thun, M.J. Pesticide exposure and risk for Parkinson's disease. Ann. Neurol. 2006, 60, 197-203. [CrossRef] [PubMed]

31. Smith, T.C.; Wingard, D.L.; Smith, B.; Kritz-Silverstein, D.; Barrett-Connor, E. Walking decreased risk of cardiovascular disease mortality in older adults with diabetes. J. Clin. Epidemiol. 2007, 60, 309-317. [CrossRef] [PubMed]

32. Hu, F.B.; Stampfer, M.J.; Solomon, C.; Liu, S.; Colditz, G.A.; Speizer, F.E.; Willett, W.C.; Manson, J.E. Physical activity and risk for cardiovascular events in diabetic women. Ann. Intern. Med. 2001, 134, 96-105. [CrossRef] [PubMed]

33. Lakka, T.A.; Laaksonen, D.E. Physical activity in prevention and treatment of the metabolic syndrome. Appl. Physiol. Nutr. Metab. 2007, 32, 76-88. [CrossRef]

34. Hilberg, T. Physical activity in the prevention of cardiovascular diseases. Epidemiol. Mech. Hamostaseol. 2008, 28, 9-15.

35. Rodriguez, B.L.; Curb, J.D.; Burchfiel, C.M.; Abbott, R.D.; Petrovitch, H.; Masaki, K.; Chiu, D. Physical activity and 23-year incidence of coronary heart disease morbidity and mortality among middle-aged men. The Honolulu Heart Program. Circulation 1994, 89, 2540-2544. [CrossRef] [PubMed]

36. Temple, B.; Janzen, B.L.; Chad, K.; Bell, G.; Reeder, B.; Martin, L. The health benefits of a physical activity program for older adults living in congregate housing. Can. J. Public Health 2008, 99, 36-40. [PubMed]

37. Sardu, C.; Marfella, R.; Santulli, G. Impact of diabetes mellitus on the clinical response to cardiac resynchronization therapy in elderly people. J. Cardiovasc. Transl. Res. 2014, 7, 362-368. [CrossRef] [PubMed]

38. Cardona, S.; Pasquel, F.J.; Fayfman, M.; Peng, L.; Jacobs, S.; Vellanki, P.; Weaver, J.; Halkos, M.; Guyton, R.A.; Thourani, V.H.; et al. Hospitalization costs and clinical outcomes in CABG patients treated with intensive insulin therapy. J. Diabetes Complicat. 2017, 31, 742-747. [CrossRef] [PubMed]

39. Gregg, E.W.; Beckles, G.L.; Williamson, D.F.; Leveille, S.G.; Langlois, J.A.; Engelgau, M.M.; Narayan, K.M. Diabetes and physical disability among older U.S. adults. Diabetes Care 2000, 23, 1272-1277. [CrossRef]

40. Kalyani, R.R.; Rodriguez, D.C.; Yeh, H.C.; Golden, S.H.; Thorpe, R.J., Jr. Diabetes, race and functional limitations in older U.S. men and women. Diabetes Res. Clin. Pract. 2015, 108, 390-397. [CrossRef] [PubMed]

41. Bardenheier, B.H.; Gregg, E.W.; Zhuo, X.; Cheng, Y.J.; Geiss, L.S. Association of functional decline with subsequent diabetes incidence in U.S. adults aged 51 years and older: The Health and Retirement Study 1998-2010. Diabetes Care 2014, 37, 1032-1038. [CrossRef]

42. McGuire, L.C.; Ford, E.S.; Ajani, U.A. The impact of cognitive functioning on mortality and the development of functional disability in older adults with diabetes: The second longitudinal study on aging. BMC Geriatr. 2006, 6, 8. [CrossRef]

(c) 2018 by the authors. Licensee MDPI, Basel, Switzerland. This article is an open access article distributed under the terms and conditions of the Creative Commons Attribution (CC BY) license (http://creativecommons.org/licenses/by/4.0/). 